\title{
CURAÇAO EN ONDERHOORIGE EILANDEN BONAIRE EN ARUBA VAN 1804 TOT 1806. HET BESTUUR VAN DEN GOUVERNEUR J. P. CHANGUION
}

(Slot)

\author{
DOOR
}

\section{B. DE GAAY FORTMAN}

Intusschen was het in het westdistrict minder voorspoedig gegaan.

In den vroegen morgen van 30 Mei 1805 werd het gerucht, dat de Engelschen zich hadden ingescheept naar Jamaica gelogenstraft door een nieuwe overrompeling van de batterij op St. Kruis. De kolonel Evertsz, die het den gouverneur berichtte, zond een krijgsgevangen matroos mee. Uit diens mededeelingen bleek, dat de Engelschen den vorigen avond met 30 man geland waren en een Hollandsch officier, van boord meegekomen, hun den weg had gewezen. Tot drie uur in den morgen had men gemarcheerd, en zonder slag of stoot de batterij - die ieder onneembaar achtte, zooals Everțsz schreef - genomen, zonder dat een schot van die zijde gelost was. 14 man werden gevangen genomen en de bombardier Olivet, door kapitein Schmidt bijzonder voor dit commando aan Evertsz aanbevolen, was gekwetst door twee bajonetsteken. De kolonel kon tot geen andere slotsom komen, dan dat ook nu weer de bezetting geslapen had.

Het was een kleine moeite om den berg te ,heroveren", daar de Engelschen die bijna even spoedig weer verlaten hadden.

3 Juni geschiedde een nieuwe landing op Porto Marie. Evertsz werd er moedeloos onder. Hij schreef dit aan den gouverneur: voor al zijn moeite kreeg hij chicanes van het gouvernement tot dank. Dit ziet wellicht op een order van den gouverneur, dat de commandanten niet meer zelf hun rapporten mochten komen uitbrengen en zich niet verder dan één uur van hun kampementen mochten verwijderen. Daarbij kwam wel typisch het gebrek aan locale kennis van den gouverneur, waarop hij zelf den 7den Mei gezinspeeld had, uit, want De Schwartz schreef, dat zijn kampement slechts drie kwartier van de stad verwijderd was. En Evertsz vond, dat de order niet op hem kon slaan, daar 
hij als commandant der zeemacht toch ook zijn verantwoordelijkheid voor de schepen in de haven had.

Er waren nog wel andere redenen om moedeloos te zijn. Er was geen medewerking van de zijde der planters. Als Evertsz hen liet waarschuwen om goed wacht te houden en hem tijdig te waarschuwen, als de Engelschen in aantocht waren, hoorde hij niets; blijkbaar zagen zij liever hun boeltje in vlammen opgaan, zooals nu weer met de plantage Fontijn gebeurd was. Daarbij werd er aan de opvorderingen van levensmiddelen slecht voldaan.

Het detachement van Evertsz was 4 Juni op de plantage Ascencion aangekomen, waar Lewe twee dagen later het bevel overnam. De kapitein der artillerie Schmidt was er op een rondreis ook aangekomen, en verder waren er van de zeeofficieren De Quartel, luitenant Soldaan 1) en ,,jonker" De Veer, van de landmacht luitenant Quast 2), de eenige officier, ,die papiments verstaat" en luitenant Michel van de artillerie.

In den nacht van den 7den Juni deden de Engelschen een welgeslaagden aanval op het kampement. De relazen over het gebeurde loopen uiteen. De gouverneur heeft rapporten laten opmaken door alle officieren, die den aanval overleefden, en deze gaven elk een eigen voorstelling. Het liefst volg ik dat van den commandant Lewe, die zich volgens aller getuigenis dapper gedragen heeft, en toen zijn pistolen leeggeschoten waren, gevangen genomen is. Het komt hierop neer:

...Terwijl een korporaal met matrozen de ronde deed, hoorde ik een musketschot. Ik riep allen in het geweer. Er vielen meer schoten. Luitenant Soldaan dekte met 12 man het veldstuk op het N.O. punt. Kapitein Schmidt, die op het eerste schot naar het veldstuk was gegaan, kwam kort daarop terug, ging snel het huis binnen zonder mij van iets rapport te doen. Ik heb hem niet weergezien. Ik zag De Quartel eenige oogenblikken op het plein. Luitenant Quast verzocht $\mathrm{ik}$ bij mij te blijven en zijn plicht als officier te doen, hetgeen hij gedaan heeft. Ook De Veer heb ik bij mij laten blijven. Er vielen verschillende schoten aan den oostkant van het magazijn, die door ons - in het geheel 18 à 20 man - beantwoord werden. Tot tweemaal toe trok de vijand terug. De vrijnegers aan onze zijde waren op het eerste vuren ge-

1) Euwens ,Curaçao in 1803-1804", blz. 63, 69 noemt hem Frederik Soldaan.

2) Johan Godfried Ernst Quast, geboren te Zwanenburg in Gulickerland, 2de luitenant provisioneel, had omstreeks 4 dienstjaren bij de West-Indische artillerie. 


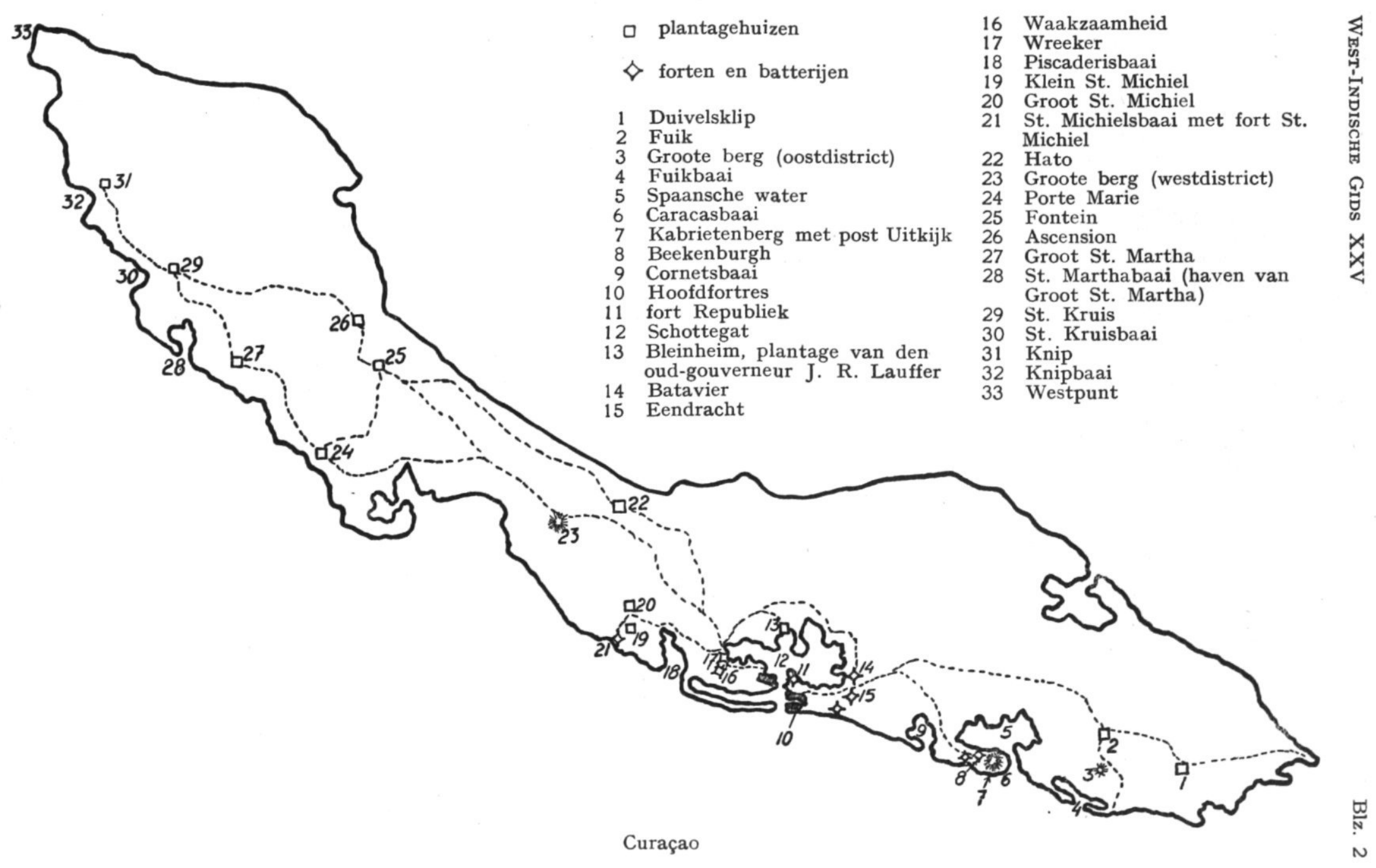


vlucht. Ik hoorde een schot van het veldstuk vallen, waarop de vijand voor de derde maal aanviel, met Hauszegger aan het hoofd, roepende: „Vuurt niet, vuurt niet!” Ten oosten en ten zuiden vanwaar wij stonden drong de vijand door. $\mathrm{Na}$ het schot van het veldstuk hoorde ik „Hoera!' roepen. Toen Hauszegger op ons aandrong, hoorde ik achter mij schieten. Een versche vijandelijke colonne kwam van den zuidwestkant op ons aan om ons in den rug aan te vallen. Ik dacht aan terugtrekken. Een man naast mij werd dood geschoten. Verschillende Engelschen wierpen zich op mij, namen mij mijn sabel en afgeschoten pistolen af en brachten mij bij de overige krijgsgevangenen: Quast, De Veer en Corn. Royer. De luitenant Soldaan en Michel waren gesneuveld. De vijand was ongeveer 130 man sterk; van ons waren er 19 jagers, 20 matrozen, 3 burgers en 10 negers geweest.

Dit relaas klopt vrijwel met dat der minder dapperen. Schmidt vertelt, dat hij luitenant Michel hoorde roepen „Avanceert! voorwaarts! vuur! vuur!' en dat hij, terwijl hij zelf het huis binnen vluchtte, den luitenant Quast toeroepende: „zij zijn te sterk, wij zullen het niet stoppen!" den overste Lewe op het plein zag staan met pistolen in de hand, roepende: „Allons, kaerels, gij houdt het wel!" Schmidts grootste heldendaad was, dat hij eenige vluchtenden naliep, hun tevergeefs toeroepende: „Staat! staat! en formeert het peloton om onze retraite te dekken!"'

De luitenant ter zee De Quartel bepaalde zich in zijn verslag tot zijn eigen dappere daden. Op het schot van het veldstuk zou hij hebben laten vuren, en op dat vuren zou de vijand aan de zuidzijde teruggetrokken zijn. Den chirurgijn Meinhardt, dien hij hoorde schreeuwen: „Sta! mannen, sta!” had hij toegeroepen: ,Meinhardt, schreeuw zoo niet, want zij zullen denken, dat wij in confusie zijn!' Hij vertelt ook, dat hij borst aan borst met een Engelsch officier heeft gestaan, die zeide: „Don 't fire!”, waarop De Quartel beval: ,,Vuur!' Met 8 à 10 man was hij tenslotte teruggetrokken, toen het veldstuk door den vijand genomen was, en hij zag, dat hij Lewe, aan de westzijde op het plein zich bevindende, niet kon helpen. ,Ik koos nu mijn leven in de waagschaal te stellen omme van onder de vijandelijke wapenen te retireeren, als slegts nog een oogenblik te blijven staan, als wanneer ik krijgsgevangen zou geweest zijn". Er was dan ook nog op hem geschoten, toen hij den berg opging. In het hofje van de plantage had hij kapitein Schmift aangetroffen met 6 jagers en matrozen, en met elkaar hadden zij zich naar Hato begeven. 
In den morgen van den 8sten Juni kwam Damascus de Ris 1), een boodschaplooper, die telkens weer voorkomt, met de Jobstijding in de stad. Hij stelde den gouverneur voor met 100 à 150 man de Engelschen op de plantage Ascension te overvallen. Daarvan kon echter geen sprake zijn. In het fort waren niet meer dan 4 jagers en een handvol ongedisciplineerde burgers, meest zonder geweren, en de bovencontreien konden niet ontbloot worden. In een bespreking met de stafofficieren werd besloten nadere berichten af te wachten, en daar was reden voor, want de Engelsche taktiek was nu eenmaal nooit lang op de plek der overwinning te vertoeven.

Dat hebben zij ook ditmaal niet gedaan. De gevangenen - hoeveel manschappen er buiten de officieren krijgsgevangen gemaakt en gesneuveld zijn, wordt niet vermeld - werden eerst aan boord van de ,Rendier" gebracht, daarna met de „Elk" naar Aruba gevoerd, en eindelijk met ,"The Superieur” naar Jamaica. Daar kregen de officieren al spoedig verlof naar Curaçao terug te keeren, maar zij hadden moeten beloven, vóór er een formeele uitwisseling tegen Engelsche krijgsgevangenen zou hebben plaats gevonden, niet tegen Engeland te zullen vechten. Murray had door een brief aan Conn den ouden heer De Veer nog laten weten, dat diens verzoek om zijn zoon vrij te laten, hem eerst bereikt had, toen deze al naar Jamaica doorgezonden was. Lewe verzocht na zijn terugkomst voor een krijgsraad te mogen terechtstaan, die over zijn gedraging zou oordeelen, maar na overleg met den waarnemenden garnizoenscommandant, den kapitein der jagers Pfeiffer 2), en den kapitein Schmidt besliste de gouverneur, dat daarvoor geen reden was; het was ,genoegzaam beweezen of immers allerwaarschijnlijk", dat het gebeurde bij Ascension door verraad van negers en de overmacht van den vijand was veroorzaakt. Lewe kreeg een schriftelijke verklaring, door Changuion, Pfeiffer en Schmidt onderteekend, dat hij zich als een „,braaf en eerlijk officier" had gedragen. In September 1805 kwam er bericht van den Engelschen Rear-admiral Dacres, dat Lewe, Quast en De Veer zich als uitgewisseld konden beschouwen 3), en dus vrij waren van hun woord, dat zij niet tegen de Engelschen zouden vechten.

1) Euwens, ,,Curaçao in 1803-1804" noemt blz. 54 : Damasco de Ries.

2) Frederik Hendrik Pfeiffer geboren te Maastricht in 1774 of 1775 was kapitein provisioneel.

3) $\mathrm{Zij}$ waren uitgewisseld onderscheidenlijk tegen 8, 4 en 6 Engelschen. 
Bij de gangbare voorstelling van Brions ,nationale” daad behoort die, dat daarmee het geheele eiland van de Engelschen bevrijd en zelfs de blokkade opgeheven is geweest. Ook dit is onjuist.

Den 25sten Juni rapporteerde Schmidt aan den gouverneur uit het westdistrict, dat de Engelschen het plantagehuis van de weduwe Van der Linden hadden afgebrand, en op de plantage van Van Uytrecht (Asencioen, Knip of Bisento) 110 hoornbeesten hadden geroofd. En in het oostdistrict is sprake van een nieuwe batterij, door de Engelschen ten zuidoosten van het vernielde fort Fuik aangelegd, die de majoor De Schwartz gemakkelijk kon vernielen, toen de Engelschen er niet waren. Ook vond de gouverneur nog aanleiding den majoor en kapiteins der burgermacht bijeen te roepen, hen te herinneren aan hun eed van trouw aan de Bataafsche republiek en hen aan te manen betere discipline te houden.

Van de gezamenlijke bemanningen der drie oorlogsschepen, een 219 man, waren er nog altijd een 120 te velde en op de batterijen, toen Evertsz den 2den Juli aan boord van de „Kenau Hasselaar" terugkeerde. De majoor De Schwartz, die twee dagen later in het hoofdfort terugkwam, stelde den gouverneur voor zijn detachement, ook wat de daarbij geplaatste matrozen en burgers betrof, met het oog op nieuwe aanvallen der Engelschen in tact te laten, en liefst nog uit te breiden met een 30 à 36 matrozen en burgers. De gouverneur prees des majoors ,,iever", en vond het goed het detachement nog te laten als het was, maar voor uitbreiding waren geen mannen beschikbaar, althans geen matrozen; uit de burgers konden nog een 17 aan het commando worden toegevoegd.

Den 14den Juli 1805 heesch het Engelsche fregat „La Franchise" de parlementaire vlag voor de haven. De commandant Murray was overleden 1) en kapitein Fyffe voerde het bevel. De parlementair kwam met een sommatie tot overgave van het eiland, ,,wijl het ten sterkste geblocqueerd stond te worden", en men wist, dat het niet lang meer te houden was. De gouverneur hield zich aan zijn vroegere brieven aan Murray. Twee dagen later vermeesterden de Engelschen de seinpost Gelderland voor de zooveelste maal.

$\mathrm{Nu}$ zal het er met de voedselvoorziening inderdaad wel niet

1) Euwens „Admiraal Pedro Louis Brion" enz. deelt mee, dat Murray op Klein-Curaçao werd begraven (blz. 296). 
best uitgezien hebben. Het blijkt niet, of de planters voldaan hadden aan den last van den gouverneur om hun maisoogst gedeeltelijk op te slaan - aan dien om bij alarm hun hoornvee stadwaarts te drijven en in de bosschen te jagen was niet voldaan - en in ieder geval waren de twee à drie maanden, die men in Mei gedacht had het nog te kunnen uithouden, wel voor het grootste deel verstreken, doch den 19den Juli kwam een Amerikaansch schip, rijk geladen met provisiën, dat aan de waakzaamheid van den vijand ontsnapt was, de haven binnen.

$\mathrm{Er}$ is in dezen tijd ook weer sprake van uitwisseling van krijgsgevangen, waarbij Curaçao altijd nog in voorschot was ${ }^{1}$ ).

Dan schijnt het eiland echter al wel van Engelschen gezuiverd te zijn, maar hun schepen kruisten nog bij de Curaçaosche eilanden. Den 31sten Juli kwam er bericht, dat een kort te voren uitgezeild vaartuig door een Engelschen golet was genomen. Velen boden zich aan om het vaartuig te gaan hernemen, en de koopman Jervey, schoonzoon van den gouverneur, stelde daarvoor een schip beschikbaar, dat met 12 jagers onder bevel van Brion, 6 matrozen en een aantal burgers bemand werd. Het gelukte inderdaad het genomen vaartuig terug te brengen.

Lewe, terug van Jamaica, had daar den indruk gekregen, dat een onderneming van gewicht tegen het eiland niet in de bedoeling lag.

Toch deed de gouverneur nog een poging den afweer van het eiland te verstevigen. De Schwartz had voorgesteld een corps van 150 kleurlingen te vormen, en Brion kreeg opdracht een corps burgers aan te werven onder den naam van ,,gesoldeerde inlandsche jagers", maar het lukte niet: slechts 3 man, van welke 2 negers waren, hadden zich laten aannemen; het plan werd opgegeven.

Changuion trachtte ook buiten 's lands hulp te krijgen: geweren en munitie en proviand. In de eerste plaats wendde hij zich daartoe tot de Spaansche commandanten op de vaste kust. Maar fortuinlijk was hij daarbij niet: veel gelukwenschen met de „opligting der bloquade”, doch wapens en krijgsbehoeften konden

1) Van Engelsche zijde trad daarbij telkens op een kapitein Van Sittart, commandant van „La Fortunée”, blijkbaar Henry van Sittart (1777-1843). Changuion noemt hem later een fatsoenlijk man blijkens zijn brieven, die, naar gezegd werd, veel op den kapitein-luitenant Sloterdijk geleek. Het speet den gouverneur hem op de terugreis naar Holland niet op Jamaica ontmoet te hebben. 
niet gemist worden; ten hoogste werd de toezegging gedaan, dat de handel zou begunstigd worden.

Brion, die naar St. Thomas ging, bracht voor den gouverneur een brief om hulp aan diens ambtgenoot op St. Martin, mr. W. H. Rink. Ook hier was het antwoord teleurstellend: ik verkeer zelf in een hachelijke positie, schreef Rink, en dat stemde overeen met Brions indruk: daar zijn ze er veel slechter aan toe dan wij.

Evertsz had weer eens een moedelooze bui, toen hij 27 Augustus den gouverneur voorloopig ontslag vroeg, om ,de onaangenaamhedens en fatiges welke zedert het begin mijner komst alhier heb uitgestaan, waardoor mijn gezondheid merkelijk benadeeld is waarom tot Herstel van dezelve in het aanstaande voor Jaar bij eene goede gelegentheid naar Europa wilde vertrekken, en mij aldaar beter bevindende mijn dienst weder daar of Elders te presteeren". Het blijkt niet, wat de gouverneur hierop geantwoord heeft; Evertsz is dienst blijven doen.

Opgelucht kon men zich voelen in den loop van het tweede halfjaar van 1805 , veilig nog niet. 25 September schreef B. Kock, die nog altijd tegen zijn zin vice-commandeur van Bonaire was, en in zijn moedeloosheid het gerucht, dat Aruba en Bonaire door den gouverneur geabandonneerd zouden zijn, geloofd had, dat er een tender was geweest van kapitein Van Sittart met bericht, dat er van Jamaica een expeditie tegen Curaçao was uitgezeild. Het zal wel bangmakerij geweest zijn.

Werkelijkheid was de bedreiging van den handel door Engelsche kapers. 12 November kwam een aantal kooplieden den gouverneur om maatregelen vragen. $\mathrm{Zij}$ voorzagen wel, dat de marine weer niet gereed zou zijn, en vroegen voor dat geval vergunning zelf een kaper uit te zenden $\left.{ }^{1}\right)$. Den volgenden dag, toen de kapergolet voor de haven gezien was, zou dan toch de „Suriname” te 4 uur kunnen uitzeilen, Brion en de oud-raad Quast zouden meegaan. Het werd 6 uur, en men was het er over eens, dat het nu geen zin meer had uit te varen.

Changuion plaatste hierbij in zijn journaal deze

„Aanmerking. Men ziet uit het voorgevallene ten opzigte van het uitzeylen, al wederom, hoe bezwaarlijk het is eenigen dienst van de alhier gestationeerde zee Magt te hebben en

1) 26 Sept. 1805 kreeg Andrew Junck voor zijn schip ,Dispath” met 15 koppen en 12 geweren een commissiebrief van Changuion, maar overschreed zijn bevoegdheden. Uitvoerig daarover een brief van den gouverneur van 22 Dec. 1805 aan den Raad der Amerikaansche koloniën. 
hoe ongelukkig en noodlottig al wat van die zijde verlangd wordt, altoos uitvalt!"

Inderdaad! en dit was niet het laatste staaltje van dien aard.

Den 14den zeilde de „Suriname” toch maar uit, 's morgens om vier uur, in de richting naar Klein-Curaçao. 's Middags van den volgenden dag was 't schip terug met een lek boven water. Het schijnt, dat de marine nu toch ook zelf wel vond, dat het al te gek was. Twee uur later kon het schip weer uitzeilen, maar toen het den 17den weer binnenliep, had het niets uitgevoerd.

Changuion had natuurlijk al dien tijd ook met geldgebrek te worstelen. Tot zijn tekort aan locale kennis behoorde ook, dat hij niet wist wie nog wel konden helpen. Daarvoor had hij een eigenaardigen raadsman, een zekeren Schlemm 1), commandeerend officier van de Roodewegs-wachtpatrouille, blijkens zijn gebroken Nederlandsch van Duitsche geboorte, die af en toe den gouverneur inlichtte over de tekortkomingen en baatzuchtigheden, de lafheden en lakschheden der burgerij. Zie hier een staaltje van briefwisseling met den gouverneur. Blijkbaar had deze hem gevraagd om een opgave van gegoede ingezetenen. Schlemm gaf die en kruiste eenige namen tot driemaal toe aan ${ }^{2}$ ).

1) Euwens, „Curaçao in 1803-1804” noemt op blz. 3 en 45 Louis Schlemm als raadslid.

2) $\mathrm{Zij}$ volgt hier:

Kooplieden :

Th. Jutting $x$

De Lima $x \times$

H. Leyer $\times$

Ib. de Solas $x \times$

Cancryn $x$

Eml. da Costa Gomez en Broeder $\times$ x

Gabriel da Costa Gomez × ×

Aron Pinedo $\times \times$

I. en C. van der Meulen $\times \times \times$

M. Cardose $\times \times$

I. Faulk $\times \times$

da Costa Gomez en Soonen $\times \times \times$

Gegoede inwooners:

Diedenhoven

Wed. de Rochemont

Mevr. Diedenhoven

de Wed. Rasvelt

H. Basden $\times$

Joh. Stuyling $\times \times \times$

fiscaal Van Starckenborgh

Mevr. Holthuysen

de Wed. Berch

G. Duykinck sal na gedagten uit

Wed. Pinedo

ambitie van $20 / \mathrm{m}$. geeven

Wed. Pine

I. R. Lauffers boedel

Marg. Jandrop

C. van Uytrecht blijft rijk, de wissels zijn goed

T. Cruger

A. de Veer $\times \times \times$

Eenigen hunner worden genoemd bij Hamelberg, ,,Een veel bewogen tijdperk" blz. 65. Gabriel da Costa Gomez bij Euwens, „Curaçao in 1803-1804", blz. 63. 
Er zij hier menschen, schreef hij, die geld hebben en het niet willen geven, en ook die het anderen afraden, maar: „Op Curaçao word het draad zo fijn gesponnen, als ooit in de Tijden van Louis de $14 \mathrm{n} . .$. De cabalisten moeten voorsigtig syn. Voorgister is er zeer sterk desaangaand gesprooken, en door mannen van moed gesegd, die, als se het dol maakten nog eens over de kling springen te laaten. Bevoor Curaçao een puinhoop worden sal, moet er nog veel gebeuren. Een seeker heer uit Den Haag schreef mij hoe 't op Curaçao was, ik antwoorde thans: Vivitur ex rapto, nec hospes ab hospite tutus, non socer a genero, fratrum quoque amicitia rara est" 1). Hij stelde den gouverneur een heffing voor, zooals er onder Lauffer een van $4 \%$ geslaagd was.

De Raad van politie had al eerder daartegen geadviseerd op grond, dat er geen fondsen waren en stremming van den handel in levensmiddelen ervan te duchten zou zijn.

Changuion sloeg een anderen weg in. Hij richtte een uitnoodiging tot 27 der gegoedste ingezetenen en planters om het gouvernement met geld tegen wissels bij te staan, en hij kreeg daarbij een aanbod tot hooger bedrag dan hij hebben moest. 12, onder wie Schlemm, hadden aan des gouverneurs verzoek voldaan.

Afdoende was deze hulp niet. Na de opheffing van de blokkade trachtte de gouverneur tevergeefs bij den gouverneur en kapitein-generaal van Venezuela een leening te plaatsen.

En nu het conflict met den majoor Larz. de Schwartz.

Van drieërlei aard zijn de moeilijkheden, die zich hebben voorgedaan. Twee er van kwamen tegelijk ter kennis van den gouverneur.

Op 5 Juli kreeg Changuion een klacht van Hansz, met Schlemm commandant van de vrijwillige Roodewegswacht, aan wie beloofd was, dat deze wacht rechtstreeks onder de bevelen van den gouverneur zou staan, dat De Schwartz niet als gewoonlijk het parool had doorgegeven. En in de tweede plaats was er een oploop van jagers geweest, waarover de majoor den gouverneur niets gerapporteerd had. De Schwartz werden hierover inlichtingen gevraagd. ,In 't generaal', aldus besloot Changuion zijn journaal van dien dag, ,,nam ik mij zelve egter voor, waakzaamer als ooit te worden omtrent 't maintien der Rechten van 't Gouver-

1) Aanhaling uit Ovidius, Metamorphoses I, 144, 145: Er wordt van roof geleefd; de gastvriend is niet veilig voor zijn gastvriend, de schoonvader niet voor zijn schoonzoon, en zelfs onder broeders komt genegenheid (amicitia moet zijn gratia) zelden voor. 
nement, en bij de eerste willekeurige aanmatiging die men zich in 't vervolg weder mogt toe eigenen, een ernstiger toon aan te neemen, en den Heer Commandant op een zeer serieuse wijze zijne Verpligtingen en Subordinatie aan 't Gouvernement onder 't oog te brengen, hem responsabel stellende voor de gevolgen die zulks anders voor hem zou kunnen hebben en voor de ernstige maatregels die hij mij zou dwingen te zijnen opzigte te nemen".

De kwestie van het parool leek zoo heel ernstig niet. Schwartz gaf op, dat hij vond, dat deze wacht het parool niet toekwam en hij den gouverneur ten dienste de zaak had willen vereenvoudigen.

Van de jagers was een deel van de soldij, twee realen, ingehouden als vergoeding voor een vernield zeil van de "Suriname". Als protest waren de jagers te hoop geloopen, maar de commandant hoopte het gevaar te bezweren. Een der grieven was, dat de matrozen niet met gelijke inhouding gestraft waren, en Evertsz had zich daartoe bereid verklaard.

De gouverneur was door deze mededeelingen allerminst bevredigd, en hij gaf order, dat onmiddellijk de soldij zonder korting zou worden uitbetaald. Schwartz en Pfeiffer wilden den gouverneur nog spreken over de wijze van uitvoering van dezen maatregel, waardoor het prestige van den majoor behouden zou blijven, maar zij werden niet ontvangen. Kapitein Pfeiffer, later ontboden, moest vertellen, dat er 10 jagers gedeserteerd waren, die een paar dagen later op Fuik door de Engelschen aan boord werden genomen. Het dreigde hoog te loopen. Van Nes bemoeide zich er mee, vertelde, dat hij gehoord had, dat nog meer jagers wilden wegloopen, en vroeg den gouverneur door een aanspraak tot de troep de gemoederen tot kalmte te brengen. Dit weigerde Changuion: hij zou zich niet ,laaten als kat gebruiken met wiens pooten men de castanjes uit 't vuur zou haalen".

Wat er van deze zaak overbleef, was, dat Schwartz volgens de verklaring van Evertsz en Sloterdijk den gouverneur onjuist had ingelicht over de bereidheid der zeeofficieren om ook van de gage der matrozen een deel in te houden voor het vernielde zeil. Dat zat den gouverneur zeer hoog.

Het ergst was het geval Boyé.

Ludwig Boyé, geboren in 1773, had op zeventienjarigen leeftijd in Holland dienst genomen bij het regiment Oranje-Nassau, dat hij twee jaren later als onderofficier verlaten had met uitzicht op bevordering bij de West-Indische troepen. Toen op Curaçao in 1796 Wiertz de nieuwe orde kwam invoeren, en sommige offi- 
cieren het eiland verlieten, legde Boyé, toen nog een der oudste onderofficieren, den nieuwen eed af, en werd hij bevorderd tot vaandrig en adjudant bij het garnizoen. De gouverneur Lauffer gaf hem een verklaring, dat hij gedurende het beleg der Franschen een der actiefste officieren was geweest en zijn functie als adjudant met alle accuratesse had waargenomen. Het beleg was er mee geëindigd, dat Lauffer de hem aangeboden Engelsche hulp aanvaardde, en zoo kwam het eiland in Engelsche handen. Boyé trad nu in Engelschen dienst als luitenant bij het zoogenaamde Curaçaosche korps, dat onder bevel stond van den kapitein Westerholt, een der nog altijd Prinsgezinde officieren, die in 1796 uitgeweken waren. Met dezen Westerholt had Boyé een oude veete: hij had den ,baron" verweten, dat deze de equipagiën der schepen tegen Wiertz trachtte op te zetten. Nu hij zijn chef was, maakte Westerholt het Boyé moeilijk en verweet hem, dat hij, nog korporaal zijnde, zou hebben getracht zijn officieren te vermoorden. Boyé vroeg ontslag en was nu buiten betrekking.

De militaire dienst was sedert voor hem gesloten, want na den vrede van Amiens werd hij getroffen door het decreet van het Staatsbewind, dat geen der officieren, die de Engelschen hadden gediend, in den Fransch-Hollandschen dienst mochten overgaan 1).

Changuion was zeer met hem ingenomen. In een brief aan den Raad van Coloniën, waarin hij vroeg Boyé voor herplaatsing in militairen dienst in aanmerking te mogen brengen, noemde hij dezen ,,een man, die zig zeer wel voordoet, die een fatsoenlijk uiterlijk heeft, en een goede opvoeding schijnt genoten te hebben". Ondanks het bezwaar van De Schwartz, die zich op het besluit van het Staatsbewind beriep, stelde Changuion den 14den Juni 1805 Boyé aan als zijn adjudant in den rang van 2den luitenant bij de gewapende burgermacht.

Toen nu Boyé den 21sten Juli met een order van den gouverneur bij De Schwartz kwam, weigerde deze hem als daartoe bevoegd te erkennen. Hij vroeg hem naar zijn papieren en wilde die niet teruggeven, vóór hij er afschriften van gemaakt had. De

1) Zie J. H. J. Hamelberg „,De slavenopstand op Curaçao in 1795” blz. 127 in Eerste jaarlijksch verslag van het geschied-, taal-, land-en volkenkundig genootschap te Willemstad Curafao; over Boyé: Koloniaal Weekblad 8 Juli 1926 en „,De oprichting der Curaçaosche schutterij” in DeWest-Indische Gids 8sten jg., blz. 102 over Boyé's verderen, weinig schitterenden, levensloop. 
gouverneur vernam dit met ,,indignatie" en gelastte onmiddellijke teruggave der stukken. De Schwartz verklaarde zijn houding hiermee, dat hij gemeend had, dat Boyé alleen als adjudant bij de burgermacht was aangesteld ${ }^{1}$ ). Het werd een heele heibel. De jagers-officieren deden den gouverneur het verzoek van Boyé alleen schriftelijke orders te behoeven aan te nemen. Zij stelden hem hierbij voor als meineedig, omdat hij bij de Engelschen dienst had genomen zonder van zijn eed aan de Bataafsche republiek te zijn ontslagen. Over de totstandkoming van dit verzoek won de gouverneur inlichtingen in bij alle officieren, en daaronder door speelde een kwestie tusschen den luitenant-kwartiermeester De Lange ${ }^{2}$ ) en den majoor, die beweerde, dat De Lange Pfeiffer had genoemd als den persoon, die De Schwartz bij den gouverneur in miscrediet gebracht had. Pfeiffer ontkende het feit en De Lange verklaarde het niet gezegd te hebben. De Schwartz plaatste den luitenant-kwartiermeester in arrest.

$\mathrm{Nu}$ was voor Changuion de maat vol. Hij vaardigde den 11 den Augustus een gouvernementsorder uit, waarbij den commandant De Schwartz arrest werd aangezegd met suspensie in deszelfs militaire charge. De luitenant-adjudant Wolff ${ }^{3}$ ) vroeg op last van den gouverneur den majoor zijn sabel af en gaf deze over aan Changuion. Pfeiffer werd met het garnizoenscommando belast. Het arrest van De Lange werd opgeheven. Tot 17 Maart 1806 bleef De Schwartz in arrest; toen vertrok hij met de ,Regulator" naar Holland om zich te verantwoorden. Changuion had zijn beschuldiging tegen De Schwartz aldus geformuleerd: miskenning van het gouvernement, hoonende behandeling van den gouverneur en onverzettelijkheid daarin 4).

Het onderzoek heeft lang geduurd, doch eindigde gunstig voor den inmiddels overste geworden commandant. Op 30 Augustus 1810 gaf de minister van de Marine en de Kolonién Van der Heim de volgende verklaring af: „Le soussigné Ministre de la Marine et des Colonies de Hollande certifie à la réquisition du Lieut-Colonel Lazzaroni de Schwartz et pour lui servir partout

1) Dat was ook zoo. 22 Juli 1805 heeft de gouverneur hem mee tot adjudant bij het garnizoen aangesteld.

2) Pieter Johan de Lange(n), geboren in 1775 of 1776 te Rotterdam.

3) Nicolaas Wolff, geboren te Maastricht in 1779 of 1780 , luitenant adjudant provisioneel.

4) De memorie van Changuion hierover aan den Raad der Amerikaansche koloniën is te vinden in $\mathrm{nr} .179$ van het archief van dezen raad. 
ou besoin sera, que d'après les rapports qui lui en sont revenus, le dit Colonel s'est emporté en vaillant et entendu militaire pendant le tems de son commandement des troupes dans l'isle de Curaçao. Qu'un mal entendu étant survenu entre le Gouverneur civil de l'isle et ledit Lieut-Colonel le premier l'a renvoyé en Europe ou l'affaire ayant été examinée il a été absous de toute inculpation moyennant quoi il s'est fait un devoir de lui délivrer le present certificat signé de sa main et le recommande à la protection de qui de droit". Schadeloosstelling was Schwartz reeds in 1808 geweigerd; wel kreeg hij een vergoeding van $f 5447,17$ voor zijn onvrijwilligen terugkeer ${ }^{1}$ ).

1805 , in welk jaar de gouverneur slechts eenmaal een officieel bericht uit het moederland ontving, en dat was nog een pakket van den Raad van 5 of 6 weken na des gouverneurs vertrek uit Holland, was wel een heel moeilijk jaar voor Curaçao en zijn gouverneur. Daaronder waren de moeilijkheden met Aruba en Bonaire wel van bijzonderen aard. Van ,,abandonneeren” dezer eilanden was geen sprake, maar door meer dan één oorzaak stond de gouverneur machteloos om de noodige hulp te verleenen. Kock van Bonaire kreeg, toen het even ging, een hoeveelheid levensmiddelen, die echter niet verder strekten dan voor een halve maand. Het verzoek om ontslag van den vice-commandeur werd eindelijk ingewilligd, en J. Palm Hzn. in zijn plaats aangesteld op 2 October. De van Mei af achterstallige traktementen werden in October uitbetaald. Ook Palm had het er niet naar zijn zin. In een brief van 22 December klaagde hij over de inwoners van het eiland, die in haat en nijd leefden, ,,dat onchristelijk is voor menschen, die anders moesten leven om Gods zegen te genieten". Op den kant van het afschrift van dezen brief staat deze eigenaardige aanteekening van Changuion: „Dat onchristelijk is. De menschen toonen met de daad, dat zij orthodox zijn in het geloof. Zij leeven als waare Catechismus-kinderen!' Hoe de gouverneur, die er nooit een voet aan wal zette, dit toch wel kan geweten hebben?!

Op het einde van het jaar heeft Changuion nog een krachtige

1) Ik dank deze inlichting aan het Krijgskundig archief te 's-Gravenhage met de mededeeling, dat zij ontleend is aan het Missivenboek van den minister. Algemeen rijksarchief aanwinsten 1807. In de oude officiersboekjes komt P. Lazzaroni de Schwartz aldus voor: 1794 sous-lieut. (Sinds 1788) in het regt. Grisons van Schmid, 1802 bij de troepen, gedestineerd voor de W.I. koloniën, 1803 capitein $8 \mathrm{e}$ Batalfon Jagers in de Amerikaansche coloniën, 1804 idem. 
poging gedaan, niet om de Engelschen van Aruba te verdrijven, zooals Euwens op rekening van Brion stelt, want de gouverneur dacht niet anders dan dat zij op enkelen na al weer weg waren, maar om dit eiland als steunpunt voor den vijand uit te schakelen. Deze opzet is niet gelukt, doch geheel roemloos was de onderneming, waaraan Brion inderdaad deelgenomen heeft, ook niet.

De ontvanger Quant, die, gelijk gezegd, door de Engelschen bij een van hun overvallen in plaats van Craneveldt tot gezaghebber was aangesteld en door Changuion was gehandhaafd, had den Engelschen niet voldaan. Er is een dagverhaal van den kapitein der Indianen Van der Biest op Aruba, loopende van 2 Februari tot 19 November 1805, waarin Quant, wordt genoemd als de persoon, die met zekeren Bislik 1) stemming tegen Craneveldt had gemaakt onder bedreiging van Engelsche maatregelen. Toen Mahling den 12den Februari op Aruba was gekomen, had hij Quant als commandeur aangesteld en hem en Bislik elk een prijsgemaakte golet ten geschenke gegeven. Het is vreemd, dat, terwijl V. d. Biest Quant doorloopend van Engelschgezindheid beschuldigt, de Engelschen zelf hem op 8 October vervingen door zekeren W. Doran. Van dezen kreeg de gouverneur 16 November een brutalen brief, maar tegelijkertijd ontving hij van andere zijde het bericht, dat de Engelsche bezetting op Aruba niet meer dan 1 onderofficier en 20 matrozen sterk was.

Deze tijding was voor den gouverneur aanleiding om den volgenden dag een bespreking te hebben met de zeeofficieren Evertsz en Van Nes over zijn plan om het eiland aan de 20 à 25 Engelschen, die zich er zouden bevinden, te ontnemen en voor het vervolg voor hen ,nutteloos" te maken. Changuion stelde voor, dat de „Suriname” onverwijld naar Aruba zou gaan, zich van de schepen daar zou meester maken, de Engelschen gevangen nemen, de roerende en vervoerbare goederen inschepen, ook de inwoners, vooral de ambtenaren, behalve de Indianen, de forten ruineeren, de huizen verbranden, ,in één woord: het Eiland

1) Changuion maakte hierbij in het brievenboek 4 Oct. 1807 deze kantteekening: ,, J. J. Bislik is altoos bekend geweest voor een gevaarlijke Engelsch-gezinde. Dit is ook bij de uitkomst gebleeken. Hij is het, die op $1^{\circ}$ Januarij 1807 de Engelsche scheepen binnen de Haven van Curą̧ao heeft helpen loozen (loodsen?)" Van het dagverhaal zelf teekende Changuion eerst in zijn journaal aan, dat hij het niet geloofwaardig vond, maar 4 Oct. 1807 maakte hij daar deze kantteekening: „Bij nadere ondervinding meen ik genoegzaame redenen gevonden te hebben, om dit Raport over het algemeen voor zeer geloofwaardig te moeten houden". 
Aruba geduurende deezen oorlog te evacueeren". Een gedeelte van het garnizoen zou moeten meegaan onder commando van kapitein Brion en luitenant Ellis of, zoo 't jagers waren, van luitenant Balfour 1). Deze troepen zouden aan het oostpunt, drie mijlen van de stad, geland moeten worden en van daar oprukken.

Natuurlijk hadden Evertsz en Van Nes bezwaren; zij vonden de onderneming te gevaarlijk. De gouverneur echter zette door en des avonds tusschen negenen en half tien zeilde de ,Suriname" uit. Niet luitenant Ellis maar luitenant Balfour ging mee met 20 jagers, Brion, J. H. Quast en nog twee burgers als vrijwilligers voor de landing. Van de bemanning der „Kenau Hasselaar" waren bovendien 1 officier en 49 matrozen op de ,Suriname" geplaatst. Aan de rapporten der verschillende prijsmeesters en een mondeling verslag van een der prijsmeesters, Thomas Born, die 27 November op Curaçao aankwam, is de volgende schets van het verloop der onderneming ontleend.

Op Maandag den 18den November met het aanbreken van den dag werden 47 man, de jagers en eenige matrozen, onder commando van luitenant Balfour aan land gezet aan den mond van het Spaansch lagoen bij de Commandeursbaai, de plaats, door Born en zekeren Ambrocius aangewezen. Ook Brion en Quast en een neger, blijkbaar om den weg te wijzen, gingen hier aan land. De landingstroepen marcheerden dadelijk op om de fortres te gaan nemen. De ",Suriname” bleef onder Engelsche vlag bijliggen, tot, na berekening, de troepen omtrent de batterij konden gekomen zijn. Het schip was intusschen verkend door een uitgaande Engelschen kaper, die, de zaak blijkbaar niet vertrouwende, was teruggezeild, en, toen de „Suriname” onder het geschut van de fortres gekomen was, met een tweetal batterijen aan den wal, een hevig vuur op de „Suriname” opende. Bovendien zag men, dat 2 stukken schoten op de gelande troepen. Men telde wel 70 à 80 man op de batterijen. Door het zwaarder kaliber konden zij de „Suriname” treffen, vóór deze met succes kon vuren. Met schoten in tuig en zeilen naderde het schip, ging bijliggen en vuurde 192 schoten af.

De troepen waren intusschen in twee pelotons, één onder Brion en één onder Balfour door het bosch gemarcheerd. Twee

1) Patrick Balfour of Burleigh (1784-1848). Op Curaçao was hij eerste luitenant der jagers. Hij huwde in 1809 in tweeden echt met Changuions dochter Henriette Wilhelmine Gerardine Elisabeth. Later werd hij garnizoenscommandant in Suriname. 
Indianen wezen de beste plaats voor den aanval aan. Ook Quant had zich bij hen gevoegd. Tot op 160 à 170 passen genaderd, werden zij uit 30 geweren beschoten. Na een half uur vuren trokken de onzen zich terug in de bosschen.

Om tijd te winnen en de geleden schade te herstellen heesch de "Suriname” de parlementaire vlag, en zond zekeren Schuurman, een oud-gediende, aan den wal om de overgave vóór zonsondergang te eischen. Doran weigerde.

Den volgenden dag, Dinsdag den 19den, werd met een barkas 's morgens Brion met een gedeelte der landingstroepen aan boord genomen, en 's middags Balfour met de rest. Dien dag werd over en weer nog flink geschoten, vooral van Engelsche zijde; de "Suriname" vond 't wijs minder krachtig te antwoorden om den indruk te vestigen, dat men niet over zooveel kruit beschikte.

De Engelsche kaper wist den volgenden dag uit te zeilen en te ontsnappen, doordat de "Suriname”, toen die aanstalten tot achtervolging makkte, vertraging kreeg, daar twee mannen, die over boord geslagen waren, moesten gered worden. Een cano van den wal bracht eenige personen, onder welke een Curaçaoenaar, Jan Flemming, en twee Indianen aan boord, die aanboden met 50 Indianen te helpen de fortres te veroveren. De batterij heesch echter de witte vlag.

De luitenant Hulsenbosch en Brion waren al aan land gegaan en bezig met de huizen in brand te steken. Balfour volgde met 40 man om ook de batterijen te ruineeren. Tegen het verbranden der huizen rees verzet bij de Indianen, en om hen, die zoo goede diensten bewezen hadden, ter wille te zijn, werd hiervan verder afgezien. Aanvankelijk had men alleen hun huizen willen sparen, maar verschillende redenen leidden ertoe, dat aan het ,nutteloos" maken van het eiland, toch eigenlijk het voornaamste doel der opdracht van den gouverneur, nagenoeg geen uitvoering werd gegeven. Op de aanzegging aan alle inwoners en ambtenaren om zich Woensdag, den 20 sten, om drie uur in den middag aan boord te bevinden, was niemand verschenen, en het vertrek had nog overhaast plaats op het valsche gerucht, dat er een fregat of linieschip om de Noord kruiste. Bovendien wilde men de inwoners niet ontstemmen, omdat men hen noodig had voor het wegbrengen der prijzen naar Curaçao, en ook in de toekomst een beroep op hun hulpvaardigheid zou kunnen moeten doen. Er warèn zes krijgsgevangenen gemaakt, slechts één matroos van Van Nes was gekwetst. De volgende prijzen waren gemaakt: de „Fortuna”, geladen met stokvischhout, die door Born op 
Curaçao werd binnengebracht, een Spaansche golet, door de Engelschen prijs gemaakt, waarop Brion als prijsmeester geplaatst was, nog een Spaansch vaartuig en een Deensche golet met muilezels, die door Schuurman 1) als prijsmeester begeleid werd. Brion is wegens averij nog op Aruba teruggekomen, en Schuurman ook, daar het schip met de muilezels niet voldoende bestuurbaar bleek. De muilezels werden de bosschen in gedreven, en Brion bracht zijn lading op het Deensche schip over.

Van Nes vermeldde met lof het gedrag der manschappen inzonderheid van Balfour, Brion, Quast en Schuurman. Erg bezwaard, dat een gedeelte zijner instructie onvolvoerd was, voelde Van Nes zich blijkbaar niet. Hij schreef in zijn rapport, dat de oorzaak hiervan moest gezocht worden in ,,de ontfangene Tijding eener overmacht en onmogelijk wegens Locaal en tijd". Doran bleek met de Engelsche kaper te zijn gevlucht. Brion stelde bij zijn terugkomst Quant voorloopig weer aan als commandeur en gaf hem daarvan een bewijs. Van Nes had dit in de haast van zijn vertrek verzuimd.

In een brief van 5 April 1806 heeft Changuion aan den Raad der Amerikaansche koloniën verder van het verloop van dezen zaak verslag gedaan. Niet lang na de expeditie waren een Engelsch linieschip en eenige Engelsche kapers op Aruba gekomen, hadden daar 100 manschappen geland, de batterijen weer opgericht, den commandeur genoodzaakt te vluchten, maar eind Januari of begin Februari het eiland weer verlaten op het bericht van de komst van een Fransch eskader in West-Indië.

Van de door de „Suriname" buitgemaakte schepen was alleen dat met muilezels prijsverklaard, als onder valsche papieren met den vijand hebbende onderhandeld; de andere schepen waren aan de eigenaren teruggegeven tot teleurstelling van velen, die op de prijsgelden hadden willen aanspraak maken. De verdeeling der prijsgelden van het prijsverklaarde schip leverde allerlei moeilijkheden op, en de gouverneur riep hierover de beslissing van den raad in. Hij teekent in dezen brief nog eens aan, dat het geenszins zijn bedoeling was geweest om buit te maken, ,en had ik voorzien dat die Expeditie zoo weinig aan het eigentlijk oogmerk (om verderen handel te beletten) zoude voldoen, ik zou dezelve zeer zeekerlijk niet hebben doen effectueeren".

1) D. Schuurman, voorheen stuurman en schrijver op de „,Kenau Hasselaar", daarna op de gouvernementssecretarie geplaatst en het volgend jaar door Changuion met de stukken tegen De Schwartz naar Holland gezonden.

West-Indische Gids XXV 
Het nieuwe jaar, 1806, was nauwelijks begonnen, of er deden zich nieuwe moeilijkheden voor, ditmaal met de Franschen, niet ongelijk aan die, waarmee de commissarissen Berch en De Veer vóór Changuion te maken hadden gehad. Onder de zoogenaamde Fransche agenten op Curaçao was zekere P. J. Gouges, een koopman, die zichzelf noemde ,,délegué" vanwege het gouvernement van St. Domingo. Toen nu 15 Januari de Fransche kaper „,L'Eulalie”, kapitein Rouillet, met een onder Aruba genomen prijs „,St. Joseph" de haven van Curaçao was binnengeloopen, ging de raad Berch met den fiskaal en den secretaris aan boord ter verzegeling van den prijs, maar zij troffen Gouges daarmee reeds bezig, die de verzegeling niet deed met het zegel van het Fransche gouvernement doch met een cachet, waarop een antiek kopje, dat hij aan zijn horloge had hangen. Voor de zooveelste maal wees Changuion Gouges er op, dat hij hem in zijn beweerde hoedanigheid niet erkende en ook niet mocht erkennen volgens de bestaande bepalingen. Gouges beriep zich op de erkenning van zijn voorgangers door Berch en De Veer, maar tevergeefs $\left.{ }^{1}\right)$. De fiskaal maakte de verzegeling van Gouges ongedaan, waarop deze de papieren afgaf 2).

Veertien dagen later maakte Rouillet zich met „L'Eulalie” onder het fort van Piscadera meester van een Deensch vaartuig, althans van een schip onder Deensche vlag, de „Lille”, geladen met koffie en hout. Changuion las Rouillet de les, en deze bood zijn verontschuldiging aan. Hij kon vertrekken met achterlating van de „St. Joseph", en de „Lille” werd vrijgegeven door den Raad van politie. De uitvoering van dit laatste besluit werd onmogelijk gemaakt door de Franschen, die aan boord van de „Lille" bleven. Ten slotte zette de gouverneur Rouillet in de provoost. Changuion genoot de voldoening, dat Ferrand op St. Domingo het gedrag van Rouillet en de vasthoudendheid van Gouges afkeurde. De zaak met de „Lille” werd geschikt, maar de gouverneur eindigde met Gouges te erkennen als ,fondé” van Ferrand ,de pouvoir personel, et special, et... l'admettre en cette qualité comme partie interessée sur le fait des prises", onder

1) En ten onrechte volgens Euwens „Curaçao in 1803-1804”, blz. 37, ofschoon deze commissarissen blijkbaar wel toegaven aan de eischen der ,,agenten" tot verkoop der prijzen (blz. 71).

2) Lodewijk Napoleon heeft bij brief van 9 Oct. 1806 het gedrag van Changuion tegenover Gouges en „,L'Eulalie” goedgekeurd (Archief van het Ministerie van Koophandel en Koloniën no. 19. Algemeen Rijksarchief). 
voorwaarde, dat hij geen daad van openbaar gezag zou doen en niet de uniform van „délegué” zou dragen. Toen „L'Eulalie” kort daarna onder kapitein La Fond weer een schip gejaagd had, hield Changuion het Fransche schip vast, en ook den kapitein, nadat deze zijn schip in de haven had laten zinken; het schip kon gelicht worden. Later heeft Gouges nog getracht ook als „fondé" van het gouvernement van Guadeloupe erkend te worden, als hoedanig zich in 1804 reeds tevergeefs zekere Richaux bij Changuion had aangemeld.

In de loop van 1806 weigerde de gouverneur nog erkenning van een consul der Vereenigde Staten van Noord-Amerika.

Moeilijkheden kwamen er even spoedig weer met de zeeofficieren. Changuions dochter was gehuwd met den Amerikaanschen koopman op Curaçao Jervey. Deze werd mishandeld door de luitenants Dominicus 1), Moqué en den chirurgijn Tappert. De gouverneur nam de zaak hoog op; hij zag er ,,een zamenweefsel van Curaçaosche intrigue" in met den toeleg zijn schoonzoon in een verachtelijk daglicht te stellen. In een brief aan den commandant Evertsz verlangde hij, dat de drie zeeofficieren in diens tegenwoordigheid en in die van den fiskaal aan hem en Jervey hun verontschuldiging zouden aanbieden of wel schriftelijk verklaren Jervey voor een man van eer te houden. De adjudant van den gouverneur Boyé wist den gouverneur nog een nieuwtje te vertellen, toen hij den brief had overgebracht. Tappert zou den vorigen avond op de kolfbaan den gouverneur een schobbejak genoemd hebben 's Middags van dien dag meende de gouverneur op te merken, dat Dominicus en Tappert hem opzettelijk niet groetten. Hij strafte hen met arrest, en wees alle tusschenkomst te hunnen gunste af. De minister heeft later des gouverneurs gedrag in deze afgekeurd. Hij verklaarde eenerzijds te begeeren, dat de gouverneur als chef ,geconsidereerd" zou worden, maar zijnerzijds had deze alles te vermijden wat aanleiding tot offensie of verwijdering zou kunnen geven.

Het zal wel aan deze en dergelijke strubbelingen te wijten zijn geweest, dat, toen Evertsz kort daarop den gouverneur met echtgenoote en kinderen uitnoodigde op een souper en bal ter eere van zijn 25-jarigen zeedienst, Changuion bedankte, ,,vermits

1) Johannes Dominicus, in 1775 te Leeuwarden geboren, was van 1787-1790 cadet bij de Oost-Indische compagnie, 1796 luitenant provisoir, 1e officier op de ,Galathé”. Mededeeling van het Krijgskundig archief. 
mijne en des Gouvernantes gezondheidsconstitutien ons niet permitteerden fêtes bij te wonen die lang in den nacht voortduurden en het een vaste wet bij ons was dat mijne Dogters niet uitgingen zonder haar moeder". Hij wenschte den commandant een ,gouden bruiloft met den zeedienst".

De buitenlandsche vijand liet den gouverneur al evenmin met rust. Al kwam het niet tot aanvallen als in het vorige jaar, er was toch alle reden om zich op afweer voor te bereiden. In Januari 1806 slaagde Changuion er nog in 267 geweren te koopen, en een paar maanden later kocht hij kruit en snaphanen van een Amerikaansch schip om te voorkomen, dat die in Engelsche handen zouden vallen. 7 Februari werden er zooveel vijandelijke schepen gezien, dat het raadzaam werd geoordeeld de haven met het hoekerschip „Marianne” af te sluiten. Toen er tien dagen later weer Engelsche schepen, eerst onder Fransche vlag, geseind waren, werd alles onder de wapenen geroepen. De schepen liepen alleen voor korten tijd de St. Kruisbaai binnen. Ook Aruba werd weer bezocht.

Over de geldelijke moeilijkheden, waarmee Changuion te kampen heeft gehad, en de wijze, waarop hij trachtte deze op te lossen, dient nog iets meer te worden gezegd.

In de eerste vergadering van den politieken Raad, dien hij bijwoonde, had de gouverneur een financieele commissie benoemd, bestaande uit de raadsleden Beutner, Cancrijn en Van Eck, den boekhouder-generaal, welker taak het zou zijn den staat der financiën exactelijk op te nemen, te overleggen over de geschiktste wijze van afdoening der schulden, middelen tot vermindering der uitgaven en verbetering der inkomsten te beramen, en een verbetering van de inrichting der administratie te overwegen, waardoor de inkomsten de uitgaven zouden dekken.

Een der euvelen, die ook in dezen tijd de geldelijke administratie kenmerkten, was de achterstand in de betaling der belastingen, met name der hoofd- en familiegelden.

Wat er noodig was aan geld blijkt uit eenige cijfers, die in de raadsnotulen voorkomen: voor September 1804 werd op den Amerikaanschen raad getrokken voor Ps. 19.756.5.3, voor October voor Ps. 11.524.-.-, voor November en December voor Ps. 33.067.4.-.

Onder de plannen, die de gouverneur overwoog tot versterking der middelen, behooren belastingverhooging, de verpachting 
van een veer over de St. Annabaai en de oprichting van een bank van leening.

In de eerste helft van 1806 ontstond er een tekort aan gangbare kleinere muntspecién, die de inwisseling van de Johanissen, de eenige rouleerende specie, doenlijk moesten maken tegen de koers van elf pesos en twee realen per Johannis. Soms moesten bij die inwisseling wel 2 of 3 realen worden prijsgegeven. De gouverneur zag hierin een blijk, ,dat eenige, hoewel gegoede, echter woekerzugtige inwooners, zich bezig gehouden hebben met het inwisselen, en woekeren met deze kleinere spetien, tot merkelijk nadeel van de Commercie in 't Generaal, als tot die der minder gegoede en der arme inwoonders van dit Eiland in 't bijzonder". Er werd toen voor 2000 pesos kaartengeld aangemaakt, t.w. 1000 stuks van 1 peso en 8000 van 1 reaal. In 's lands kassen werden die aangenomen voor 8 realen de peso; naar die maatstaf gerekend, was tot onderpand voor de waarde een gelijke hoeveelheid gangbare speciën in de landkas gestort. Ook een ieder partıculıer was verplicht tegen de genoemde waarde het kaartengeld aan te nemen op straffe van bij weigering als vijand van de rust en aanrander van de veiligheid van het eiland beschouwd te worden, en zonder vorm van proces verbannen te worden, ongeacht de actie van den raad-fiskaal.

Er is een brief van het ministerie van Koophandel en Koloniën van 12 December 1806, die uitvoerig over den geldelijken toestand van Curaçao handelt en het financieel verslag van den gouverneur, welke brief dezen niet meer bereikt heeft. De minister verklaart hierin het eens te zijn met de opgegeven oorzaak van den diep vervallen staat van het financiewezen op Curaçao, t.w. de vermindering van den handel met de Spaanschen kust, de algeheele stremming van den handel met San Domingo en den voortdurenden staat van oorlog en de rampen, die Curaçao daarin getroffen hebben. Het herstel van dit alles moet wachten op den vrede, maar andere oorzaken, die er ook zijn, kunnen en moeten onmiddellijk weggenomen worden. Daartoe behooren de steeds vermeerderende slapheid in de invordering der gewone lasten en de verregaande verwarring in de administratie der financiën, gevoegd bij de indolentie onder vele ambtenaren in het betrachten van hun plichten. Daarom werd den gouverneur voorgeschreven aanstonds een commissie of kamer van financiën of rekening in te stellen, bestaande uit den boekhouder-generaal als voorzitter en twee der eerlijkste gegoedste en aanzienlijkste ingezetenen. De taak dezer kamer, die ook voor Aruba en Bonaire 
zou werken, werd in den brief uitvoerig uiteengezet; zij is te vergelijken met die van de Algemeene rekenkamer. De oud-boekhouder-generaal Beaujon zou honorair lid der kamer moeten worden, om, voor zooveel zijn gezondheid het zou toelaten, raad te geven.

Buiten noodzakelijkheid zou niet meer op het moederland getrokken mogen worden. Omtrent belastingherziening, bezuiniging op ambtenaren en de oprichting van een bank van leening werden aanwijzigingen gegeven.

Uit den brief leert men ook de schuldeischers der koloniale kas kennen: de W.I.C. voor Ps. 549.750.-.3, de consignatiekas 20.069.4.2, de Weeskamer 29.408.4.2, P. F. Diedenhoven voor 58.000.-.-, 8.000.--- en 25.272.2.1 pesos, I da Costa Gomez en broeders 8.000.-.-, Levin Jones 12.224.4.1 voor kruit en lood ten tijde van het Guadeloupiaansche beleg onder Lauffer, schip The Mary 59.689.6.3 en den Engelschen admiraal uit Lauffers tijd Lord H. Seymour Ps. 2.812.4.- voor voorgeschoten achterstallige soldijen tot op den dag van de komst der Engelschen in 1800.

Op bestuursgebied had Changuion nog een bepaalde taak te vervullen. Hem was de opdracht gegeven - en kort na zijn komst had hij zich daarover al met den fiskaal en den advocaat mr. C. P. Römer in verbinding gesteld -- de justitie te leggen in handen van een zelfstandig college met hem, gouverneur, als voorzitter zonder stem, een vice-president, en 7 rechters, uit de ingezetenen aan te wijzen. In afwachting van de komst van een vice-president uit Holland had de gouverneur den raad van politie provisioneel belast met de rechtspraak. $\mathrm{Nu}$ was dan besloten, dat de raadfiskaal Van Starckenborgh vice-president zou worden. Het werd hem gemakkelijk gemaakt door het traktement van den fiskaal van $f$ 8000.- op $f 3000$. - te brengen, en dat van den vicepresident van den raad van justitie op $f 6000$. - te stellen. Maar dan moest er een nieuwe fiskaal komen. Daarvoor had de gouverneur gedacht aan mr. B. Blok 1), die uit Holland verwacht werd, bestemd tot eersten secretaris van het gouvernement. Hij zou nog wel wat op zich laten wachten, en daarom werd de inrichting van het rechterlijk college voorloopig uitgesteld. Het duurde tot 18 December, voor de installatie kon plaats vinden met 5 leden

1) Mr. Bernardus Blok (1756-1818), werd later (1808) raad van justitie in Batavia en in 1813 in rechterlijke betrekking te Alkmaar benoemd. 
van den raad van politie als leden, waarmee de bedoeling de justitie van de ,politie” te scheiden, zeker niet bereikt werd, en het was maar voor kort, want de Engelschen herstelden den ouden toestand.

Changuion moest voortgaan met Aruba en Bonaire onverdedigd te laten. Hij kon er geen schepen en geen soldaten voor missen. Zoo had met name Aruba telkens weer te lijden van Engelsche bezetting, en tot tweemaal toe, van 10 tot 15 April en van 19 Augustus tot 10 September, hield De Miranda het eiland bezet ${ }^{1}$ ).

Den 1sten Mei 1806 werd de nieuwe staatsregeling der Bataafsche republiek, die van 1805, afgekondigd. Zij kwam tegelijkertijd met een bedankbrief van den Raad der Amerikaansche Koloniën aan den gouverneur voor de verdediging van Curaçao van 28 Februari tot 31 Juli 1805.

Het was ook verder het parool, dat de Raad aan zijn gouverneurs uitgaf: verdedigt de koloniën! Hoe zullen wij dat kunnen? schreef Rink van St. Martin aan Changuion, er is niet één geweer voor de burgerij en de geweren voor het 150 man sterke garnizoen zijn meerendeels defect. Changuion had nog wel een plan van verdediging van zijn commandant der artillerie Schmidt, maar dat was toekomstmuziek en hij had het naar den Amerikaanschen raad in Holland gezonden.

Toen er een verzoek van kooplieden kwam om meel te mogen uitvoeren liet Changuion den voorraad eerst beschrijven. Het viel geweldig mee. De uitvoer van 1500 vaten werd toegestaan, en er bleef dan nog voor meer dan 70 dagen over.

De Engelschen bleven voor de haven kruisen. 25 Augustus teekent de gouverneur aan, dat hij maatregelen genomen had om de burgerij in den wapendienst te oefenen. Wie op de excercities niet verscheen, zou beboet worden. Als sterkte van de gewapende burgermacht wordt opgegeven 850 man, waarvan 348 afwezig, verdeeld over 6 compagnieën infanterie en 4 artillerie. De kooplieden beklaagden zich erover, dat schepen van Curaçao naar Bonaire door de Engelsche schepen werden aangehouden, dan vrijpassen kregen, maar daarvoor inlichtingen verstrekten

1) ,Urbina-Miranda. Een bladzijde uit de geschiedenis van het eiland Aruba" in De Indische Gids Jan. 1931. 
over op Curaçao tot vertrek gereed liggende of daar verwacht wordende schepen.

Changuion, die nog altijd ontstemd was over den toon, die tegen het gouvernement werd aangeslagen ${ }^{1}$ ), was heel boos over dezen brief, vroeg bewijzen, en toen deze niet kwamen, berispte hij de klagers ernstig, en droeg den fiskaal op tegen alle aanvallen op het gouvernement op te treden, maar toch vaardigde hij een order uit, dat, zoolang er Engelsche kruisers vóór de haven waren, wekelijks niet meer dan één vaartuig naar Bonaire zou mogen gaan, en dat geen lid van de bemanning aan boord van vijandelijke schepen mocht gaan, terwijl de vice-commandeur van Bonaire bericht kreeg, dat alle handel met de Engelsche kruisers verboden was.

Merkwaardig is, dat in dezen tijd - het was inmiddels October geworden - allerlei vredesgeruchten rondgingen. De fiskaal hoorde die van de binnenkomende schepen, en een brik van Jamaica wist zelfs te vertellen, dat de vrede „oogenblikkelijk" verwacht werd.

Changuion vertoeft dan met zijn familie geruimen tijd buiten, en wel ,op het buitenplaatsie van den Heer Lauffer", (die naar Holland was om zich te verantwoorden over zijn overgave der kolonie aan de Engelschen) ,,tot herstel zijner zeer verzwakte gezondheid", het bestuur binnen de fortres aan den fiskaal overlatende. Dit beteekent niet, dat de gouverneur zich niet met de zaken bemoeide. Integendeel. 6 December was hij twee maanden buiten en teekende toen in zijn journaal aan, dat hij nog acht dagen daar zou blijven, om ,gezet en gerust aan zommige depeches te kunnen arbeiden en mij verder te herstellen daar ik mij nog zwak gevoelde". 13 December nam de gouverneur het commando van den fiskaal over.

Intusschen kwam 29 November eindelijk het bericht, dat al eenige maanden als gerucht was rondgegaan, dat Lodewijk Napoleon koning van Holland was geworden. Dat gaf weer een heele deining. Den 16den December zou de eedsaflegging en daarna een groote maaltijd zijn. Eerst weigerde kapitein Joh. van Nes, de commandant van de "Suriname" aan te zitten met , ,lieden van de couleur”. Dat ging tegen drie of vier kapiteins van de burgermacht. Hoe dit opgelost is, blijkt niet. Verder weigerden onder aanvoering van den bootsman van de „Kenau Hasselaar", Joseph Bakker, eenigen van de bemanning den eed,

1) Zie ook het geval-Erkelens in De West-Indische Gids 22ste jg. blz. 255 . 
als reden o.a. opgevende, dat zij niet van den ouden eed ontslagen waren, ,,dan zijnde dit soort van oproer dadelijk door de officieren gestuit, die er met de bloote sabels op hadden ingehouwen en eenige der belhamers geblesseert en in de boeyen doen sluiten, waarna de Equipage den eed hadden gedaan". Bakker werd den volgenden dag ter dood veroordeeld door den krijgsraad. De approbatie van het vonnis, aan den gouverneur gevraagd, weigerde deze als niet behoorende tot zijn bevoegdheid; wel gaf hij ,,fiat executie” op een der schepen. Die zou 18 December om 10 uur, met spoed, omdat men oproer vreesde, op de „Kenau Hasselaar” geschieden. De batterijen waren bezet met artillerie, om bij het eerste teeken op de „Kenau Hasselaar” te schieten. In den raad zijnde, kreeg de gouverneur een verzoek om mitigatie van de gereformeerde en luthersche predikanten, di. Van Esch en Muller, en van de pastoors Schenck en Pirovano. De gouverneur deelde mee, dat hij ten hoogste surchéance zou kunnen verleenen, tot in Holland was beslist. Met moeite werd de krijgsraad er toe gebracht bij meerderheid van stemmen te verklaren, dat hij in den toestand onder de bemanning geen bezwaar tegen surchéance zag. Toen werd die door den gouverneur verleend.

Ondanks deze tragische gebeurtenis ging het feest door. Het gouvernementshuis was verlicht. In het midden was een tempel afgebeeld, in welks frontespice met vergulde, verlichte letters te lezen was „Vivat Louis Napoleon”, terwijl op de venstervakken, verlicht door driekleurige lampions, stond „Koning van Holland". Aan den maaltijd dronk de gouverneur op Lodewijk Napoleon, het koninkrijk, den keizer Napoleon en den minister van Koophandel en Koloniën. Als bijzonderheid wordt vermeld, dat ook de Roomsch Katholieke priesters aanzaten.

Eenige dagen later was de gouverneur met de bevelhebbers van zee- en landmacht te gast bij den vice-president van den raad van justitie Van Starckenborgh. Eerst kwam er bericht, dat 1 Engelsch fregat, 2 brikken en 4 kleine vaartuigen voor de haven zich als parlementairen aandienden. Een oogenblik later werd een brief gebracht van kapitein Bolton, commandant van de „Fisgard" met uitnoodiging de kolonie onder de bescherming van Zijne Britsche Majesteit te stellen, anders zou aanstonds de blokkade beginnen en daarna een aanval op de kolonie gedaan worden. Changuion vroeg pen en inkt aan Van Starckenborgh en schreef, dat hij trouw bleef aan zijn op den 16den gezworen eed. Terwijl de maaltijd voortging, had aan een der vensters een bespreking 
plaats tusschen den gouverneur, den commandant der artillerie Schmidt, den garnizoens commandant Pfeiffer en Evertsz, den commandant der zeemacht. Er werd besloten, dat Schmidt de batterij ook 's nachts zou doen bezetten. Over de sluiting van de haven was men ongerust, want eenige maanden geleden was de hoeker ,Marianne” weggenomen, daar zij vergaan was en anders zou gezonken zijn. Schmidt stelde voor de „Suriname” en „Kenau Hasselaar” aan den mond der haven te leggen. Hij vond gehoor bij Changuion en Pfeiffer, maar Evertsz was er tegen, omdat deze schepen dan voor de batterij de Waag in den weg zouden liggen, of zelf aan het vuur van deze batterij zouden zijn blootgesteld. Hij zegde toe bij een aanval deze schepen eenige vademen naar voren te zullen brengen, neus aan neus, en dan zou het vuur van de schepen en van de batterijen den Engelschen wel zooveel eerbied inboezemen, dat hun de lust spoedig zou vergaan om binnen te komen of te trachten de haven te forceeren. Zoo werd het afgesproken.

Den 31sten December des morgens om 11 uur werd een vijandelijke brik geseind, opkomende van beneden, die tegen den middag op de hoogte der haven op eenigen afstand in de zuid naar boven opwerkte. Pfeiffer kwam om één uur rapport doen.

En nu volgt letterlijk het slot van Changuions journaal:

„Ik vroeg zijne gedachten over de voor de haven zeylende Engelsche Brik, te kennen geevende dat dezelve mij opmerkzaam maakte, omdat wij juist eenige dagen te vooren gesommeerd waren, en dat ik in beraad stond of ik niet beter zou doen in het Fort te blijven en niet naar buiten te gaan (zijnde mijn voornemen geweest 's namiddags naar buiten te vertrekken om er den Nieuwjaardag en 2 volgende dagen door te brengen en Zondags 4 Januari terug te komen) vreezende, dat de Brik veelligt een voorzeylder was, en misschien door meer scheepen zou gevolgd worden, en men mogelijk iets in het zin zoude hebben. De Commandant antwoordde zaakelijk dat hij niet zag dat ik mij voor die eene brik behoefde te geneeren of ongerust te maken, dat ik zijns oordeels gerust naar buyten kon gaan, vooral daar ik zoo digt bij de hand bleef, dat ik op het eerst signaal altoos binnen een quartier binnen het Fort kon zijn. en dat hij mij tot mijne geruststelling beloofde mij zoodra er meer scheepen op mogten komen, den Luitenant Quartiermeester de Lange te paard te zullen toezenden om mij te informeeren daar ik dan altoos meester zou zijn om des goedvindende terstond naar het fort te kunnen retourneeren, maar dat ik verzekert kon zijn, dat zoodra men 
maar mine maakte om iets te entameeren (verondersteld dat er meer scheepen bij de Brik kwamen) hij mij onverwijld het sein om binnen te komen zou laaten maaken, en die allarm schooten zou laaten doen, en ik dan bij mijn arrivement alles klaar en in orde vinden zou, maar dat hij wel niet geloofde, dat die brik eenig gevolg hebben zou.

Bij nader inzien vind ik er dus geen de minste zwarigheid voor mij in om naar buiten te gaan, en besloot dus mijn gemaakt plan te volvoeren, doch daar het oudejaarsdag was en men apres tout niet weeten kon wat er soms kan gebeuren, en ook om de order te maintineeren, gaf ik den Commandant te kennen dat hij mij, daar ik naar buyten ging, plaisir zou doen, binnen het Fort te blijven, en op alles een waakzaam oog te doen houden, waarop de commandant mij geantwoord heeft, dat ik er staat op kon maaken en dit mijn te kennen geeven voor hem zoo goed als een order was, waarna zijn Ed. zig retireerde.

Kort daarna begaf ik mij aan tafel en na de middagmaaltijd, nog eens naar de brik uitziende, zag ik dat dezelve zuidoostwaarts opzeylde en zig meer en meer verwijdert.

Tusschen vijf en zes uur begaf ik mij met mijne vrouw en kinderen naar buyten".

Hier eindigt het journaal van den gouverneur. Het lijdt m.i. geen twijfel, of Changuion heeft dit slot geschreven na de gebeurtenissen van den oudejaarsnacht, hetzij nog op Curaçao hetzij later in Holland, toen hij, gelijk ik in het begin van dit opstel opmerkte, de beschikking over zijn journalen gehad heeft.

1 Januari 1807 viel Curaçao in Engelsche handen, en hiermee was dan een einde gemaakt aan het bestuur van den gouverneur Changuion.

Gelijk ik reeds zeide, is er reden om over deze gebeurtenis en wat daarmee samenhangt te raadplegen de nog ongebruikte bronnen, op het Algemeen rijksarchief te 's Gravenhage aanwezig. Daarom wordt het oordeel over des gouverneurs beleid in vollen omvang opgeschort. Uit hetgeen aan dien oudejaarsnacht en nieuwjaarsmorgen voorafging mag wel een voorloopige slotsom getrokken worden. Deze is, dat gouverneur Changuion de 27 maanden van zijn bestuur nagenoeg onafgebroken met groote moeilijkheden te kampen heeft gehad, evenals Lauffer en het tweemanschap Berch en De Veer, zijn onmiddellijke voorgangers. De blokkade en de Engelsche landingen waren het zwaarst, en konden niet bestreden worden met een onvoldoende landmacht 
en misschien een honderdtal goedwilligen in de burgermacht. Het overgroote deel van deze laatste bestond uit lijntrekkers en plichtverzakers, en de zeemacht bleek eigenlijk nooit tot iets in staat. Op Aruba en Bonaire was op geen wijze het Nederlandsche gezag te handhaven. En als de buitenlandsche vijand de kolonie even met rust liet, waren er binnenlandsche strubbelingen, die in grooter verband van onbeduidenden aard zouden geweest zijn, maar in deze drie maatschappijtjes de aandacht van den gouverneur vroegen. Voeg daarbij het voortdurende geldgebrek, de nagenoeg verbroken verbinding met het moederland 1) en de droeve geschiedenis van Curaçao in deze jaren is geteekend en verklaard 2). De indruk van Changuions beleid is: hij heeft zijn best gedaan, en krachtiger figuren zouden in deze omstandigheden evenmin geslaagd zijn ${ }^{3}$ ).

Amsterdam 25 Augustus 1942.

1) $\mathrm{Na} 20$ maanden ontving de gouverneur voor het eerst stukken van den Amerikaanschen raad.

2) Jhr. mr. J. C. de Jonge, Het Nederlandsche zeewezen, blz. 633 verhaalt, dat de Engelsche landingen in 1805 ,,ook door den krachtigen bijstand der zeelieden, mannelijk... afgeslagen" werden, en dat op 16 Nov. 1805 Aruba ,,door de vereenigde land- en zeemagt uit Curaçao... veroverd" werd op de Engelschen. Als ook hier, gelijk ten aanzien van eenige mededeelingen over de verrassing van Curaçao op 1 Jan. 1807, De Quartel De Jonge's zegsman is geweest, dan is aan diens oordeel weinig waarde te hechten. De Jonge zegt van de inwoners van het eiland voorts, dat zij ,,over het algemeen... zeer Engelschgezind" waren.

3) Hieruit volgt, datik mij niet vereenigen kan met de voorstelling, die Changuion zelf van zijn beleid geeft in de Memorie, die hij in 1814 voor den Souvereinen Vorst opstelde op diens verlangen om ,,in zijnen zamenhang te weten, wat er op Curaçao bij gelegenheid der overgave dier Colonie aan de Engelschen, op den eersten Januarij des Jaars 1807 , was voorgevallen". Het eerste gedeelte, 10 bladzijden, behandelt wat aan den nieuwjaarsdag van 1807 voorafging. Hij vertelt daarin, dat hij uitgezonden werd op een nieuwe instructie, waarin hem zeer gewichtige werkzaamheden met betrekking tot de reorganisatie der kolonie werden opgedragen. Hij meent, dat hij daaraan in alle opzichten heeft voldaan: de orde heeft hij gehandhaafd, de disharmonie tusschen burgers en militairen beteugeld, de gewapende burgermacht gereorganiseerd en op beteren voet gebracht door invoering van ,,gepaste" reglementen van administratie en discipline, door geregelde wapenoefeningen, zoodat daaruit een aanmerkelijk ,,soutien" voor het garnizoen kon getrokken worden, en tenslotte prijst hij zijn gedrag tegenover den Franschen agent Gouges. 